doc. dr. sc. Marko Tomljanović

Ekonomski fakultet, Sveučilište u Rijeci, Rijeka, Republika Hrvatska marko.tomljanovic@efri.hr

\title{
UKLJUČIVANJE ZEMALJA ZAPADNOGA BALKANA U EUROPSKU UNIJU - STANJE I POTENCIJALNI EKONOMSKI UČINCI
}

Primljen: 26. lipnja 2018.

Prihvaćen: 31. kolovoza 2018.

Pregledni rad

\section{Sažetak}

Suočene sa nepovoljnom gospodarskom i socijalnom situacijom, a koja je nastala kao izravna posljedica prethodnih ratnih događanja te političkih previranja, zemlje Zapadnoga Balkana su kao najvažniji gospodarski i strateški cilj odredile ostvarivanje punopravnoga članstva u EU. Cilj provedenoga istraživanja je pregledom teorijskih i povijesnih spoznaja o integracijskim kretanjima u zemljama Zapadnoga Balkana te analizom gospodarske situacije utvrditi trenutačnu poziciju ove skupine zemalja u europskim integracijskim procesima. Svrha istraživanje je utvrditi potencijalne učinke punopravnoga članstva u EU na ostvarivanje gospodarskoga i socijalnoga napretka u zemljama Zapadnoga Balkana. Istraživanjem je utvrđeno osjetno zaostajanje ove skupine zemalja za prosjekom EU, što predstavlja izazov u provođenju efikasnih strukturnih reformi. Punopravnim članstvom u EU ova skupina zemalja će dobiti mogućnost poslovanja na Unutarnjem tržištu EU te korištenje EU financijskih instrumenata, a što će predstavljati temelj za značajno ubrzavanje i poboljšanje gospodarskih performansi te povećanje međunarodne konkurentnosti.

Ključne riječi: EU, IPA, kriteriji iz Kopenhagena, politika proširenja, Zapadni Balkan

JEL: F15, F63 


\section{UVOD}

Razmatranje definirane problematike je neophodno započeti teorijskim određenjem pojma Zapadni Balkan. Pritom, najbolji uvid u situaciju u ovome dijelu Europe daje teza francuskoga povjesničara Andrea Blanca, prema kojem ,,pojam Balkana označava problem, a ne regiju“. Općenito, prema Altić Slukanu (2009) definiranje Zapadnoga Balkana karakterizirano je složenim političkim kontekstom i međunarodnim odnosima, pri čemu je pojam uvelike određen povijesnim kontekstom, a ne geografskim uvjetima, sa naglašeno negativnom konotacijom. Kao glavne karakteristike pojma moguće je izdvojiti geografsku nedefiniranost te, kao što je prethodno navedeno, izraženu kulturološku negativnost.

Uvidom u relevantne bibliografske jedinice, vidljiva je prilično nejasna definicija balkanskoga poluotoka. Naime, balkanski poluotok se najčešće definira kao jugoistočni dio europskoga kontinenta, čija je kopnena granica određena linijom Trst - Odesa. Nadalje, Encyclopedia Brittannica određuje balkanski poluotok kao regiju koju čine sve zemlje bivše Jugoslavije, uključujući Sloveniju, Bugarska, Rumunjska, Grčka te Albanija, a na koju se nadovezuje The Palgrave Concise historical Atlas of the Balkans, prema kojem su kao sjeverne granice Balkana određene Drava, Dunav, Karpati te ušće rijeke Prut u Crno more. World Geographical Encyclopedai definira Balkan kao Podunavsko - balkansku regiju, a koju čine Grčka, Albanija, Makedonija, Srbija, Crna Gora, BiH, Hrvatska, Mađarska, Rumunjska i Bugarska. Tijekom 20. stoljeća, pojam Balkana se često zamjenjivao i poistovjećivao sa pojmom jugoistočne Europe, čime je obuhvaćeno široko područje između Jadranskoga i Crnoga mora. Najvažniji nedostatak ovoga pristupa, temeljnoga uglavnom na povijesnom nasljeđu, proizlazi iz činjenice da je njime obuhvaćen samo središnji dio južne Europe. Autori ističu kako je upotreba pojma jugoistočna Europa opravdana samo u slučaju u kojem se Rusija ne smatra dijelom Europe.

Daljnja afirmacija pojma Zapadni Balkan je započela nakon pada Berlinskog zida, kada su definirane osnovne karakteristike balkanskoga područja i balkanizacije. Pritom, Encyclopedia Brittanica navodi ključne karakteristike spomenute regije, i to: ,fluidnost etničkih skupina, nesposobnost naroda u regiji da se međusobno slažu i surađuju, sklonost zloporabi vlasti na lokalnoj razini čim oslabi središnja vlast, značajan utjecaj stranih sila te poteškoće u prihvaćanju koncepata razvijenih u drugačijem političkom i društvenom kontekstu. " Također, prema Klemenčiću (1999), balkanizacija podrazumijeva „raspad nekoga područja na male i međusobno neprijateljske jedinice“.

Topalović (2000) ističe da, usprkos čestoj upotrebi, pojam Zapadni Balkan nije još uvijek prisutan u relevantnoj i službenoj politološkoj literaturi. Navedenim 
pojmom se opisuje strategija EU prema zemljama bivše Jugoslavije (s iznimkom Slovenije i dodatkom Albanije).

Intenzivnije korištenja pojma Zapadni Balkan je započelo u 90-im godinama 20 . stoljeća, pri čemu je potrebno izdvojiti najvažnije događaje, i to: 1) Politiku regionalnoga pristupa za zemlje Zapadnoga Balkana iz 1997. godine, 2) Pakt o stabilnosti i pridruživanju iz 1999. godine te 3) Europsku strategiju za zemlje Zapadnoga Balkana iz 2003. godine. Naposljetku, prema Milardoviću (2000), ključni trenutak afirmacije pojma Zapadni Balkan predstavlja izvješće EU pod naslovom „Uloga Unije u svijetu“, a čiji sedmi dio ima naslov „Odnosi s zemljama zapadnog Balkana“. Takvim pristupom zapadni Balkan je određen kao područje bivše Jugoslavije s izuzetkom Slovenije i dodatkom Albanije. Također, Milardović (2000) ističe kako „zapadni Balkan ne označuje samo virtualni politički pojam nego i jedinstvenu geografsku regiju, svojevrsnu ,pod-Europu“, definirano prvenstveno određenom vanjskom politikom EU prema navedenom prostoru“.

Pristup definiranju zapadnog Balkana predložen od strane EU (zemlja bivše Jugoslavije, s izuzetkom Slovenije i dodatkom Albanije) predstavlja temelj za istraživanje koje je provedeno u ovome radu. Naravno, iz konteksta istraživanja navedene tematike isključena je i Republika Hrvatska budući da je ona 2013. godine postala punopravna članica EU. Stoga, u ovome radu su pojmom Zapadni Balkan obuhvaćene Albanija, Bosna i Hercegovina, Crna Gora, Kosovo, Makedonija i Srbija.

Problem istraživanja provedenoga u ovome radu proizlazi iz povijesnih hipoteka te ratnih i ostalih političkih previranja na prostorima promatranih zemalja, a koja su za izravnu posljedicu imala nepovoljna gospodarska i socijalna kretanja. Navedena situacija ograničava provedbu strukturnih reformi te predstavlja ključno ograničenje $\mathrm{u}$ integracijskome putu ove skupine zemalja prema punopravnome članstvu u EU. Cilj provedenoga istraživanja je pregledom teorijskih i povijesnih spoznaja o integracijskim kretanjima u zemljama Zapadnoga Balkana te analizom gospodarske situacije utvrditi trenutačnu poziciju ove skupine zemalja u europskim integracijskim procesima. Svrha istraživanje je utvrditi potencijalne učinke punopravnoga članstva u EU na ostvarivanje gospodarskoga i socijalnoga napretka u zemljama Zapadnoga Balkana.

Premda je EU već više od desetljeća orijentirana na probleme i moguće učinke uključivanja zemalja Zapadnoga Balkana u EU, hrvatska znanstvena javnost još uvijek ne posvećuje dovoljnu pažnju ovoj tematici. Naime, uključivanje ovih zemalja će zasigurno imati značajne učinke na gospodarska, a prvenstveno 
sigurnosna kretanja u regiji, iz čega proizlazi znanstvena opravdanost provedenoga istraživanja.

Rad se sastoji od pet međusobno povezanih poglavlja.

Nakon uvodnih razmatranja u kojima je detaljno obrazložen pojam Zapadnoga Balkana te definirani ključni elementi istraživanja, u drugome poglavlju je, na temelju ključnih makroekonomskih pokazatelja, provedena analiza gospodarskoga stanja u ovim zemljama te su pritom identificirani ključni problemi. Istraživanje je nastavljeno teorijskim pregledom kriterija i cjelokupnoga pregovaračkoga procesa, a koji zemlje Zapadnoga Balkana moraju ispuniti u svrhu ostvarivanja punopravnoga članstva u EU. U četvrtome poglavlju su identificirani potencijalni učinci uključivanja u EU na gospodarstva ovih zemalja. Istraživanje završava zaključkom, a koji predstavlja sintezu ključnih spoznaja do kojih se došlo u tijeku istraživanja.

\section{ANALIZA GOSPODARSKOGA STANJA U ZEMLJAMA ZAPADNOGA BALKANA}

U ovome dijelu rada je provedena deskriptivna analiza gospodarskoga stanja u zemljama Zapadnoga Balkana. Pritom, kao najvažniji gospodarski pokazatelji su analizirani razina BDP-a per capita (u američkim dolarima) te stope rasta BDP-a ( u \%), u razdoblju 2000.-2016. godine. Nadalje, gospodarsko stanje je ocijenjeno na temelju analize strukture zaposlenosti (\% ukupne zaposlenosti), dodane vrijednosti pojedinih sektora (\% BDP-a), deficita trgovinske bilance (\% BDP-a) te stope nezaposlenosti (\% radne snage) u 2016. godini. Korišteni podatci su prikupljeni iz statističke baze Eurostat te Svjetske banke.

Zemlje Zapadnoga Balkana su ostvarivale stalno povećanje razina BDP-a per capita do 2008. godine. Ipak, usporavanja započinju, pod teretom globalne ekonomske krize, u 2009. godini (Tablica 1).

Tablica 1. Kretanje BDP-a per capita u zemljama Zapadnoga Balkana u razdoblju 2000.-2016. godine (u američkim dolarima)

\begin{tabular}{|c|c|c|c|c|c|c|c|}
\hline $\begin{array}{c}\text { Godina/ } \\
\text { Zemlja }\end{array}$ & Albanija & $\begin{array}{c}\text { Bosna i Her- } \\
\text { cegovina }\end{array}$ & $\begin{array}{c}\text { Crna } \\
\text { Gora }\end{array}$ & Kosovo & Makedonija & Srbija & EU \\
\hline 2000. & 555,30 & 1461,75 & 1627,04 & 1087,76 & 1854,15 & 870,14 & 18256,52 \\
\hline 20001. & 526,17 & 1524,41 & 1909,58 & 1490,36 & 1815,92 & 1634,88 & 18419,21 \\
\hline 2002. & 711,18 & 1761,54 & 2106,24 & 1587,51 & 1961,20 & 2149,91 & 20030,38 \\
\hline 2003. & 779,47 & 2214,73 & 2789,11 & 1969,56 & 2408,80 & 2832,49 & 24293,46 \\
\hline 2004. & 1041,09 & 2650,64 & 3380,20 & 2135,33 & 2762,56 & 3331,23 & 27939,61 \\
\hline 2005. & 1443,99 & 2968,41 & 3674,62 & 2190,55 & 3037,75 & 3528,13 & 29108,61 \\
\hline
\end{tabular}




\begin{tabular}{|l|l|l|l|l|l|l|l|}
\hline 2006. & 2062,42 & 3404,32 & 4383,60 & 2371,66 & 3325,61 & 4129,76 & 30936,21 \\
\hline 2007. & 2878,84 & 4180,29 & 5957,15 & 2788,48 & 4036,14 & 5458,12 & 35597,59 \\
\hline 2008. & 3868,58 & 5078,31 & 7367,75 & 3254,86 & 4793,29 & 6701,77 & 38135,41 \\
\hline 2009. & 3347,84 & 4701,33 & 6727,11 & 3209,69 & 4543,89 & 5821,31 & 33977,44 \\
\hline 2010. & 3529,05 & 4614,83 & 6682,28 & 3283,21 & 4542,90 & 5411,88 & 33687,59 \\
\hline 2011. & 4299,01 & 5054,33 & 7318,74 & 3712,61 & 5064,04 & 6423,29 & 36412,97 \\
\hline 2012. & 4598,25 & 4722,01 & 6586,72 & 3586,15 & 4698,69 & 5659,38 & 34230,95 \\
\hline 2013. & 4804,62 & 5042,58 & 7186,43 & 3877,03 & 5211,50 & 6353,83 & 35584,58 \\
\hline 2014. & 4709,31 & 5204,24 & 7378,35 & 4054,72 & 5469,22 & 6200,17 & 36666,65 \\
\hline 2015. & 3695,79 & 4584,24 & 6514,27 & 3574,48 & 4834,14 & 5237,26 & 32196,57 \\
\hline 2016. & 3308,70 & 4808,41 & 7023,54 & 3661,43 & 5237,15 & 5426,90 & 32233,49 \\
\hline
\end{tabular}

Izvor: izrada autora na temelju Svjetske banke (1), 2017.

Trenutačno, najviše razine BDP-a per capita među promatranim zemljama imaju Crna Gora, Makedonija i Srbija, dok je BDP per capita najniži u Albaniji. Ipak, potrebno je istaknuti kako su sve promatrane zemlje u usporedbi sa početkom razdoblja ostvarile višestruko povećanje BDP-a per capita, što upućuje na njihovo značajno napredovanje. Međutim, usporedbom sa prosjekom EU, vidljivo je još uvijek značajno zaostajanje ove skupine zemalja, a što predstavlja značajan izazov u daljnjim integracijskim procesima te provođenju kvalitetnih strukturnih reformi. Prema podatcima Eurostata (2018), Albanija se prema razinama BDP-a nalazi na $29 \%$ prosjeka EU, a slijede ju Bosna i Hercegovina, koja se nalazi na $32 \%$ te Makedonija i Srbija, koje su na 37\% prosjeka EU. Najbolje stanje je u Crnoj Gori, čiji se BDP nalazi na razini 46\% prosjeka EU.

Također, vidljivo je kako su zemlje Zapadnoga Balkana ostvarivale veće stope gospodarskoga rasta od prosjeka EU, a što je u konvergencijskim teorijama označeno kao temeljna karakteristika zemalja u razvoju. U promatranome razdoblje ove su zemlje rasle prosječno $4,3 \%$, a što je gotovo trostruko brži rast od EU prosjeka (Tablica 2).

Tablica 2. Rast BDP-a u zemljama Zapadnoga Balkana u razdoblju 2000.-2016. godine $(\%)$

\begin{tabular}{|c|c|c|c|c|c|c|c|}
\hline $\begin{array}{c}\text { Godina/ } \\
\text { Zemlja }\end{array}$ & Albanija & $\begin{array}{c}\text { Bosna i Her- } \\
\text { cegovina }\end{array}$ & $\begin{array}{c}\text { Crna } \\
\text { Gora }\end{array}$ & Kosovo & Makedonija & Srbija & EU \\
\hline 2000. & 6,67 & 5,50 & 3,10 & n/a & 4,55 & 7,76 & 3,87 \\
\hline 20001. & 7,94 & 4,40 & 1,10 & 26,97 & $-3,07$ & 4,99 & 2,21 \\
\hline 2002. & 4,23 & 5,30 & 1,90 & $-0,70$ & 1,49 & 7,12 & 1,35 \\
\hline 2003. & 5,77 & 4,00 & 2,50 & 5,98 & 2,22 & 4,42 & 1,31 \\
\hline 2004. & 5,71 & 6,10 & 4,40 & 2,61 & 4,67 & 9,05 & 2,57 \\
\hline 2005. & 5,72 & 8,76 & 4,19 & 6,03 & 4,72 & 5,54 & 2,11 \\
\hline 2006. & 5,43 & 5,38 & 8,57 & 4,50 & 5,14 & 4,90 & 3,35 \\
\hline 2007. & 5,90 & 5,73 & 10,66 & 7,29 & 6,47 & 5,89 & 3,08 \\
\hline
\end{tabular}




\begin{tabular}{|c|c|c|c|c|c|c|c|}
\hline 2008. & 3,76 & 5,58 & 3,49 & 2,64 & 5,47 & 5,37 & 0,48 \\
\hline 2009. & 3,35 & $-2,99$ & $-5,80$ & 3,34 & $-0,36$ & $-3,12$ & $-4,36$ \\
\hline 2010. & 3,71 & 0,87 & 2,73 & 3,31 & 3,36 & 0,58 & 2,12 \\
\hline 2011. & 2,55 & 0,96 & 3,23 & 4,62 & 2,34 & 1,40 & 1,69 \\
\hline 2012. & 1,42 & $-0,82$ & $-2,72$ & 2,81 & $-0,46$ & $-1,02$ & $-0,43$ \\
\hline 2013. & 1,00 & 2,35 & 3,55 & 3,44 & 2,93 & 2,57 & 0,26 \\
\hline 2014. & 1,77 & 1,15 & 1,78 & 1,22 & 3,63 & $-1,83$ & 1,74 \\
\hline 2015. & 2,23 & 3,07 & 3,39 & 4,08 & 3,84 & 0,76 & 2,31 \\
\hline 2016. & 3,37 & 3,06 & 2,95 & 3,40 & 2,41 & 2,80 & 1,94 \\
\hline Prosjek & 4,15 & 3,43 & 2,88 & 4,80 & 2,90 & 3,36 & 1,51 \\
\hline
\end{tabular}

Izvor: izrada autora na temelju Svjetske banke (2), 2017.

Nadalje, točniju sliku o gospodarskoj situaciji u pojedinim zemljama je moguće dobiti i analizom dodane vrijednosti te zaposlenosti u ključnim sektorima (primarni sektor, sekundarni sektor te tercijarni sektor), a što je prikazano u Tablici 3.

Tablica 3. Struktura dodane vrijednosti (\% BDP-a) i zaposlenosti (\% ukupne zaposlenosti) u zemljama Zapadnoga Balkana u 2016. godini

\begin{tabular}{|c|c|c|c|c|c|c|}
\hline & \multicolumn{2}{|c|}{$\begin{array}{c}\text { Dodana vrijednost sektora gospo- } \\
\text { darstva (\% BDP-a) }\end{array}$} & \multicolumn{2}{c|}{$\begin{array}{c}\text { Zaposlenost po sektorima (\% } \\
\text { ukupne zaposlenosti) }\end{array}$} \\
\hline $\begin{array}{c}\text { Zemlja/Poka- } \\
\text { zatelj }\end{array}$ & Primarni & Sekundarni & Tercijarni & Primarni & Sekundarni & Tercijarni \\
\hline Albanija & 22,8 & 23,73 & 53,37 & 41,79 & 18,2 & 40 \\
\hline $\begin{array}{c}\text { Bosna i Herce- } \\
\text { govina }\end{array}$ & 7,73 & 28,06 & 64,19 & 18,2 & 30,39 & 51,4 \\
\hline Crna Gora & 9,03 & 19,13 & 71,83 & 7,69 & 17,29 & 75 \\
\hline Makedonija & 9,88 & 29,7 & 60,4 & 16,29 & 29,5 & 54,2 \\
\hline Srbija & 7,87 & 31,31 & 60,81 & 19,6 & 24,6 & 55,79 \\
\hline Kosovo & 13,41 & 21,08 & 65,49 & n/a & n/a & n/a \\
\hline EU & $\mathbf{1 , 5 5}$ & $\mathbf{2 4 , 5 3}$ & $\mathbf{7 3 , 9 1}$ & $\mathbf{4 , 4 9}$ & $\mathbf{2 3 , 9 4}$ & $\mathbf{7 1 , 5 5}$ \\
\hline
\end{tabular}

Izvor: izrada autora na temelju Svjetska banka (3), (4), (5), (6), (7), (8), 2017

Podatci o sektorskoj strukturi upućuju na još uvijek visoke razine udjela poljoprivrednoga sektora u gospodarstvima zemalja Zapadnoga Balkana, pri čemu najveće vrijednosti ostvaruju Albanija, Kosovo te Makedonija. Prosječna razina udjela poljoprivrednoga sektora u BDP-u zemljama Zapadnoga Balkana je $11,78 \%$, što je višestruko više od EU prosjeka. Također, zastarjelost poljoprivrednih gospodarstava te njihova orijentiranost na malu, obiteljsku proizvodnju, ne može u perspektivi predstavljati temelj ostvarivanja gospodarskoga rasta. Što se tiče industrijskoga sektora, najviše udjele ostvaruju Srbija, Makedonija, Bosna i Hercegovina, dok je zastupljenost industrije najmanja u Crnoj Gori i na Kosovu. 
Također, Crna Gora i Kosovo te Albanija imaju niže razine udjela industrije od EU prosjeka. Industrijski sustavi u zemljama Zapadnoga Balkana su uvelike karakterizirani orijentacijom na tradicionalne industrijske sektore, uz značajan nedostatak inovacija i nužnost unaprjeđenja poslovnih i organizacijskih procesa. Stoga, u uvjetima globalizacije, a posebno deindustrijalizacije, industrijski sustavi ovih zemalja zahtijevaju značajne reforme u svrhu prilagodbe zahtjevima suvremenoga poslovnoga okruženja te ostvarivanja međunarodne konkurentnosti. Analizirajući zastupljenost uslužnoga sektora u BDP-u, vidljivo je kako Crna Gora ostvaruju veće udjele od EU prosjeka. Međutim, ostale zemlje značajno zaostaju, što svakako predstavlja izazov u kontekstu provedbe daljnjih strukturnih reformi. Također, zaostajanje u ovome segmentu predstavlja izazov obrazovnim sustavima u kontekstu usavršavanja i prilagodbe radne snage suvremenim zahtjevima tržišta.

Slično kao i u slučaju sektorske strukture, zemlje Zapadnoga Balkana još uvijek imaju visoku razinu zaposlenosti u primarnome sektoru, pri čemu prednjače Albanija, Srbija i Bosna i Hercegovina. U ovoj situaciji značajno ograničenje daljnjem razvoju predstavlja niska razina obrazovanja ruralnoga stanovništva te napuštanje sela od strane mladoga i obrazovanoga stanovništva. Također, kao ključna ograničenja je potrebno istaknuti i probleme obrazovanja žena, sklonost prema inovacijama i pokretanju efikasnih reformi. Što se tiče zaposlenosti $u$ industrijskom sektoru, ona je u Bosni i Hercegovini, Makedoniji i Srbiji viša od EU prosjeka. Međutim, zbog prethodno istaknute tradicionalne orijentiranosti industrijskoga sektora, a posebno radne snage, postavlja se pitanje njegove uloge u daljnjem napretku ovih zemalja. Kao prioritet se nameće poticanje razvoja industrije u izmijenjenim uvjetima tj. reindustrijalizacija, a koja je kao prioritet određena u ključnim strateškim dokumentima Unije. Nadalje, podatci ukazuju i na zaostajanje ove skupine zemalja u zaposlenosti $u$ tercijarnome sektoru, a što predstavlja značajan izazov za obrazovne sustave te ističe nužnost daljnje orijentacije prema društvu znanja tj. ulaganjima u istraživanje i razvoj i njihovim produktima.

Također, ove zemlje se kontinuirano suočavaju sa visokim razinama nezaposlenosti (Tablica 4). Što se tiče vanjske trgovine, kao jedan od ključnih razloga postojećega stanja potrebno je istaknuti nisku razinu međunarodne konkurentnosti ove skupine zemalja, s orijentacijom na izvoz proizvoda niske dodane vrijednosti te njihovu energetsku ovisnost. Daljnji napredak u ovome području će podrazumijevati daljnje napore u implementaciji ekonomije znanja te stvaranje tehnološki naprednih proizvoda visoke dodane vrijednosti, čime će se unaprijediti ukupna razina izvoza, s posebnim naglaskom na stvaranje i izvoz proizvoda visoke tehnologije. 
Tablica 4. Deficit trgovinske bilance (\% BDP-a) i nezaposlenost u zemljama Zapadnoga Balkana u 2016. godini

\begin{tabular}{|c|c|c|}
\hline Zemlja/Pokazatelj & $\begin{array}{c}\text { Deficit trgovinske bilance (\% } \\
\text { BDP-a) }\end{array}$ & $\begin{array}{c}\text { Stopa nezaposlenosti } \\
\text { (\% radne snage) }\end{array}$ \\
\hline Albanija & $-9,6$ & 15,1 \\
\hline Bosna i Hercegovina & $-5,07$ & 26 \\
\hline Crna Gora & $-18,01$ & 17,7 \\
\hline Makedonija & $-2,73$ & 23,7 \\
\hline Srbija & $-3,95$ & 15,3 \\
\hline Kosovo & $-9,09$ & $\mathrm{n} / \mathrm{a}$ \\
\hline EU & & 8,52 \\
\hline
\end{tabular}

Izvor: izrada autora na temelju Svjetska banka (9) i (10), 2017.

Ipak, kao najveći problem i izazov zemalja Zapadnoga Balkana je moguće izdvojiti visoke stope nezaposlenosti. Podatci ukazuju kako najviše stope nezaposlenosti među promatranim zemljama imaju Bosna i Hercegovina, Makedonija i Crna Gora. Općenito, prosječna razina nezaposlenosti u zemljama Zapadnoga Balkana je na razini $21,26 \%$, a što je gotovo trostruko veće od EU prosjeka. Ovakva situacija nameće potrebu temeljitih reformi tržišta rada, osiguravanje uvjeta za zapošljavanje, s posebnim naglaskom na mlado i obrazovano stanovništvo te definiranje mjera i instrumenata, a koji će kao rezultat imati poboljšanje situacije na tržišstu rada.

$\mathrm{Na}$ temelju provedene analize potvrđena je početna teza o nepovoljnoj gospodarskoj i socijalnoj situaciji u zemljama Zapadnoga Balkana, pri čemu su kao najveći izazovi prepoznati relativno nepovoljna struktura gospodarstva i zaposlenosti, visoka stopa nezaposlenosti te uvozna orijentiranost gospodarstva. Proces pristupanja EU zahtijeva značajan angažman nositelja društvene, gospodarske i političke aktivnosti $u$ ovim zemljama $u$ ispunjavanju propisanih kriterija i zahtjeva. Prilagodba pravnoj stečevini EU te zahtjevima suvremenoga poslovnoga okruženja stvoriti će temelje za gospodarski i socijalni napredak ovih zemalja. Ipak, ostvarivanje punopravnoga članstva u EU je dugotrajan i složen proces koji se ne događa preko noći te se ove zemlje nalaze pred nizom zahtjevnih izazova na putu prema ostvarenju svojega cilja. 


\section{TEORIJSKA UTEMELJENOST PRIDRUŽIVANJA ZEMALJA ZAPADNOGA BALKANA U EU}

\subsection{Kriteriji uključivanja и EU}

Općenito, prema članku 49 Ugovora o funkcioniranju EU (UFEU), ,svaka europska zemlja koja poštuje načela izražena u članku 2 istog Ugovora (načela ljudskog digniteta, slobode i jednakosti, demokracije $i$ vladavine prava itd.) $i$ koja ih je spremna promovirati, može postati članica Unije “. S druge strane, Lisabonskim ugovorom iz 2009. godine, uveden je članak 50 UFEU $^{1}$, prema kojem svaka zemlja članica može zatražiti istupanje iz punopravnog članstva u EU. Nadalje, članak 50 UFEU podrazumijeva pregovore o izlasku s obzirom na prethodno preuzete obveze. Također, ukoliko do dogovora ne dođe, Ugovor o članstvu prestaje dvije godine nakon službenoga zahtjeva za napuštanjem Unije.

Pridruživanje novih zemalja članica u EU određeno je sa dvije temeljne skupine kriterija $^{2}$ tj. kriteriji iz Kopenhagena iz 1993. godine te kriterij iz Madrida, iz 1995. godine. (Kandžija i Cvečić, 2010). Kriterije iz Kopenhagena čine politički, pravni i gospodarski kriterij. Pritom, politički kriterij podrazumijeva ,postojanje stabilnih institucija koja će omogućiti provođenje demokracije, vladavine prava, zaštite prava manjina i ljudskih prava“. Nadalje, gospodarski kriterij podrazumijeva ,postojanje učinkovitog tržišnog gospodarstva spremnog za suočavanje sa rastućom konkurencijom“. U ovom slučaju Sauron (1997) određuje temeljne karakteristike koje determiniraju postojanje efikasnoga tržišnog gospodarstva: 1. formiranje ponude i potražnje putem slobodnoga tržišnog natjecanje, 2. nepostojanje značajnih prepreka za ulazak i izlazaka sa tržišta, 3. postojanje konsenzusa o ekonomskoj politici, 4. prihvatljivost sustava privatnoga vlasništva i sporazumijevanja, 5. makroekonomska stabilnost u skladu sa Maastrichtskim kriterijima te 6. razvijenost financijskoga sustava koji usmjerava štednju prema proizvodnim investicijama. Naposljetku, pravni kriterij ,podrazumijeva obvezu prihvaćanja pravne stečevine EU u zemljama kandidatima“.

Madridski ili administrativni kriterij predstavlja nadopunu kriterijima iz Kopenhagena te se njime propisuje postojanje i prilagodba administrativnih struktura $u$ svrhu uspješne prilagodbe integraciji.

Suočena sa potencijalnim pristupanjem zemalja Zapadnoga Balkana, obilježenih povijesnim hipotekama, političkim nestabilnostima, nepovoljnom gospodarskom

1 Ovaj članak je prva aktivirala Velika Britanija, čiju su se građani na referendumu održanom 2016. godine izjasnili za izlazak iz EU. Time je započeo proces poznat pod nazivom BREXIT.

2 Naravno, zemlje prvenstveno moraju ,posjedovati“ geografski kriterij, koji nalaže da se u ovom slučaju mora raditi o zemlji koja se svojim većim dijelom nalazi na europskome kontinentu. 
i socijalnom situacijom, EU je 2003. godine definirala i ,dodatne“ kriterije za ovu skupinu zemalja, u svrhu stabilizacije ovoga područja. Navedeni kriteriji podrazumijevaju suradnju sa Međunarodnim kaznenim sudom u Haagu, brigu o povratku izbjeglica i zaštitu manjina, osiguranje prava medija, reformu pravosuđa te poticanje regionalne suradnje i razvoja te dobrosusjedskih odnosa (Kandžija i Cvečić, 2010).

\subsection{Postupak pridruživanja i integracijski kapacitet EU}

Postupak pridruživanja u EU je složen i dugotrajan proces, koji zahtjeva prilagodbu gospodarskoga i pravnoga sustava pravnoj stečevini EU. U razmatranju procesa pridruživanja, Kandžija i Cvečić (2010), ističu šest najvažnijih etapa: 1) slanje zahtjeva za članstvo, 2) početak pristupnih pregovora, 3) Akcijski plan, 4) nacrt pristupnoga ugovora, 5) potpisivanje pristupnoga ugovora te 6) ratifikacija.

Postupak pridruživanja započinje slanjem zahtjeva za punopravno članstvo, a o čemu trebaju biti obaviješteni nacionalni parlamenti te Europski parlament. Zahtjev se potom predaje Vijeću ministara. Ocjena usklađenosti sa temeljnim kriterijima predstavlja temelj za donošenje jednoglasne odluke Europske Komisije. Ukoliko je mišljenje pozitivno, saziva se međunarodna konferencija između zemlje kandidata i Unije te se zemlji dodjeljuje status službenoga kandidata. Kao službena kandidatkinja zemlja može koristiti pristupne instrumente te ostale „mjere“ potrebne za pokretanje reformi i poticanje gospodarskoga i društvenoga razvoja.

Sljedeća etapa podrazumijeva početak pristupnih pregovora, a pri čemu je potrebna preporuka Europske komisije te jednoglasna odluka Vijeća ministara. U sklopu pristupnih pregovora, za svaku je zemlju kandidatkinju određen pregovarački okvir sa smjernicama za pregovore. Nadalje, Komisija utvrđuje spremnost pojedine zemlje za članstvo kroz postupak screeninga tj. analitičkog pregleda i usporedbe nacionalnoga zakonodavstva sa pravnom stečevinom EU³ ${ }^{3}$ Na temelju rezultata screeninga, sastavlja se Akcijski plan, kojim su propisane mjere i instrumenti koje zemlja mora provesti u svrhu ostvarivanja daljnjega napretka. Također, uz pomoć pristupnog partnerstva se određuju potrebne reforme i financijska pomoć za njezino dobivanje. Nakon što zemlja kandidat uspješno zatvori sva poglavlja, detaljni uvjeti pristupanja ulaze u nacrt pristupnog ugovora, kojim se određuje datum uključivanja i potrebne institucionalne prilagodbe. Nadalje, nacrt pristupnoga ugovora uključuje prijelazne mjere, rokove $\mathrm{i}$ instrumente.

Pravna stečevina kojoj svaka zemlja kandidatkinja mora prilagoditi svoje nacionalno zakonodavstvo se sastoji od 35 poglavlja, pri čemu Vijeće ministara za svako poglavlje određuje mjerila za njegovo otvaranje ili zatvaranje. 
Pristupni ugovor moraju, nakon jednoglasne odluke Vijeća ministara, ratificirati sve zemlje članice te sama zemlja kandidatkinja ${ }^{4}$. Također, ovisno o političkom i ustavnopravnom uređenju zemlje, kao jedan od instrumenata ratifikacije se provodi referendum, na kojem stanovništvo izražava svoj stav o pristupanju Uniji (Ministarstvo vanjskih i europskih poslova Republike Hrvatske, 2017).

Uslijed velikih proširenja ${ }^{5}$, kojima je obilježeno razdoblje nakon 2000-ih godina, EU je počela, u svrhu zaštite i osiguranja pravilne implementacije pravne stečevine te ostvarenja najvažnijih gospodarskih ciljeva, uvoditi tzv. zaštitne klauzule. Upravo su u vrijeme povijesno najvećeg proširenja 2004. godine, uvedene dvije nove zaštitne klauzule, a koja se odnose na gospodarske aktivnosti sa prekograničnim učincima tj. uzajamno priznavanje u kaznenome pravu i građanskim pitanjima. Pritom je potrebno izdvojiti posebnu zaštitnu klauzula koja se odnosi na Unutarnje tržište te posebnu zaštitnu klauzulu u području pravosuđa $i$ unutarnjih poslova. Također, EU ističe i važnost suspenzivne klauzule prema kojoj „u slučaju ozbiljnog i stalnog kršenja načela slobode i demokracije, poštivanja ljudskih prava i temeljnih sloboda te vladavine prava na kojima je utemeljena Unija " može zemlji kandidatkinji odgoditi ili ograničiti punopravno članstvo u EU (Kandžija i Cvečić, 2010).

Cjelokupno odvijanje i „obujam“ proširenja ovisi prvenstveno o integracijskome kapacitetu tj. sposobnosti Unije za prihvat novih zemalja članica. Integracijski kapacitet, općenito, označava sposobnost i spremnost Unije da ostvaruje svoje ciljeve i efikasno donosi odluke, usporedno sa procesom proširenja. Emerson et al. (2006) identificiraju elemente integracijskoga kapaciteta, i to: 1) kapacitet tržišta roba i usluga, 2) kapacitet tržišta rada za apsorbiranje novih članica, 3) kapacitet financija EU, 4) sposobnost EU institucija za funkcioniranje s novim članicama, 5) sposobnost europskog društva za prihvaćanje novih članica te 6) sposobnost Unije da osigura stratešku sigurnost.

S druge strane, Europska komisija (2016) navodi službene komponente integracijskoga kapaciteta, tj. 1) institucionalnu komponentu, 2) učinak na politike EU, 3) financijsku komponentu te 4) komunikacijsku strategija (Slika 1).

$4 \quad$ Motivirana događajima u Španjolskoj, Belgiji i Škotskoj, EU je krenula u razmatranje situacije u slučaju osamostaljenje ili odvajanja određene regije unutar pojedine zemlje. U tom slučaju, ,nova država“ mora proći cjelokupni proces primanja u članstvo kroz pripreme i pregovore.

5 Proces proširenja EEZ/EU je započeo 1973. godine, kada se u punopravno članstvo, između ostalih zemalja, uključila i Velika Britanija. Daljnja proširenja su nastavljena 1981., 1986., 1995., 2004., 2007. te 2013. godine, kada je Republika Hrvatska postala 28. članica EU. 
Slika 1. Službene komponente integracijskog kapaciteta EU

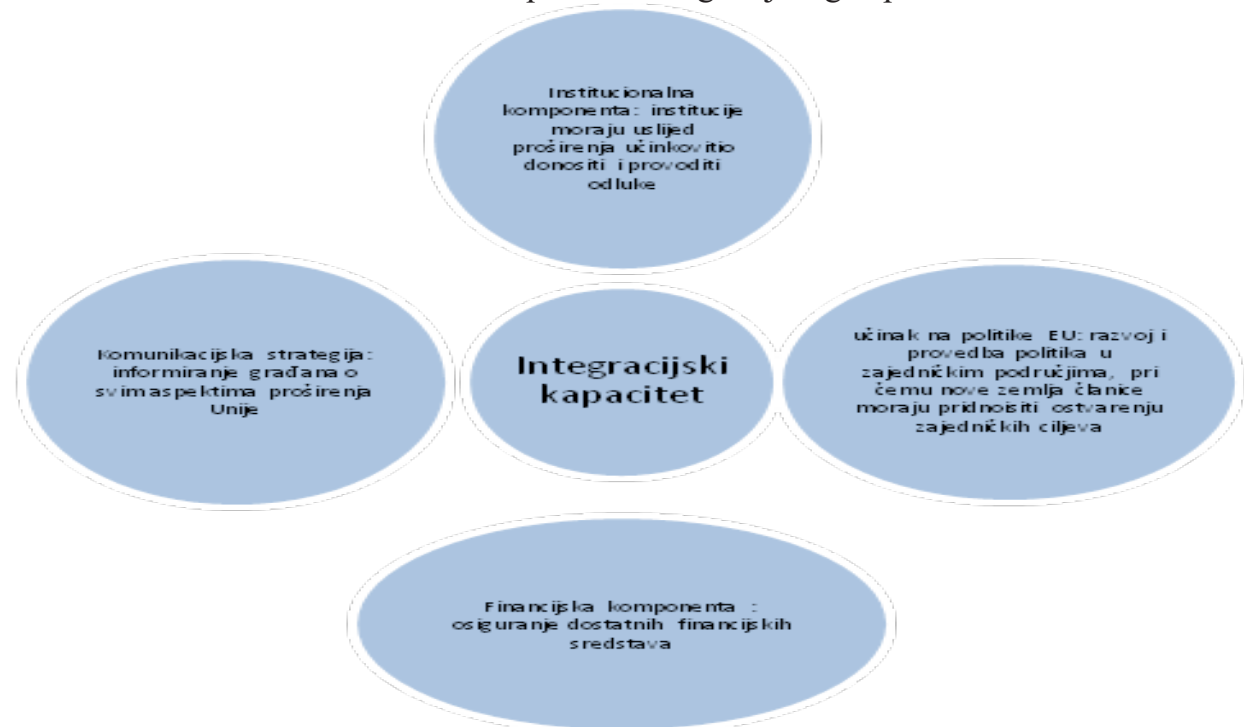

Izvor: izrada autora prema klasifikaciji Europske komisije, 2016.

Na temelju prethodno analiziranih elemenata, moguće je zaključiti kako je proces proširenja izazovan, složen i najčešće dugotrajan proces, a koji podrazumijeva prilagodbu gospodarskih, političkih i zakonodavnih struktura kriterijima i pravnoj stečevini EU. Upravo u svrhu ostvarenja napretka te osiguranja stabilnosti, EU je fokus svojega djelovanja stavila na zemlje Zapadnog Balkana.

\subsection{Položaj zemalja Zapadnoga Balkana u EU integracijskim procesima}

Ključni korak u stabilizaciji regije predstavlja Pakt o stabilnosti Jugoistočne Europe koji je usuglašen 1994. godine u Koelnu. Cilj Pakta je postizanje stabilnosti regije kroz uključivanje u euroatlantske integracije te poticanje međusobne suradnje. Proces stabilizacije i pridruživanja (PSP) predložen je 1999. godine u Solunu te je motiviran regionalnim pristupom, a sve u svrhu utvrđivanja ekonomskih i političkih preduvjeta za razvoj bilateralnih odnosa. PSP je prihvaćen 2000. godine na zagrebačkom samitu. Godine 2003. u Solunu je definirana Europska perspektiva za zemlje Zapadnog Balkana ključne uključene u PSP.

PSP je kreiran za svaku zemlju posebno te uključuje gospodarsku i financijsku pomoć, politički dijalog, prostor slobodne trgovine, usklađivanje zakonodavstva sa pravnom stečevinom EU te suradnju u područjima pravosuđa i unutarnjih poslova. 
Strategija EU prema zemljama jugoistočne Europe je određena kroz Sporazum o stabilizaciji i pridruživanju (SSP), poticanje gospodarske suradnje, financijsku pomoć, politički dijalog, poticanje suradnje te pomoć u demokratizaciji i zaštiti temeljnih prava. Sporazum o stabilizaciji i pridruživanju predstavlja novu generaciju sporazuma koji ima za cilj osiguranje suradnje EU i zemalja jugoistočne Europe, usklađivanje zakonodavstva, razvoj gospodarskih odnosa te poticanje regionalne suradnje u sklopu PSP-a. Sporazum sadrži i evolutivnu klauzulu kojom se zemlji dodjeljuje status potencijalnog kandidata i čime joj se na neki način jamči buduće punopravno članstvo u EU. Prije nego Sporazum stupi na snagu, zemlje potpisuju Privremeni sporazum, a kojim su uređena trgovinska pitanja.

Makedonija je prva od zemalja regije potpisala Sporazum o stabilizaciji i pridruživanju 2000. godine, a koji je stupio na snagu 2004. godine. Nadalje, Makedonija je postala službena kandidatkinja za članstvo u EU 2005. godine, međutim još uvijek nije dogovoren termin početka pregovora. Kao glavne razloge takve situacije je moguće izdvojiti neslaganja oko naziva države, etnička i povijesna pitanja i problemi sa Bugarskom te unutarnja pitanja s posebnim naglaskom na integraciju albanskoga stanovništva (Europska komisija (2), 2017). Sporazum o stabilizaciji i pridruživanju je 2006. godine potpisala Albanija i on je stupio na snagu 2009. godine. Albanija je postala službena kandidatkinja 2014. godine, međutim pregovori još uvijek, unatoč inicijativi Europske komisije iz 2016. godine, nisu započeli. Albanija u narednome razdoblju mora posvetiti značajnu pažnju demokratizaciji društva, transparentnosti te borbi protiv korupcije, a što je identificirano kao najveći izazov u procesu njezine daljnje integracije u EU (Europska komisija (3), 2017). Srbija je Sporazum o stabilizaciji i pridruživanju potpisala 2008. godine, a on je stupio na snagu 2013. godine. Dvije godine nakon odobrenja statusa službenoga kandidata (2012. godine), Srbija je, nakon održavanja međuvladine konferencije, započela pregovore o članstvu u EU (Europska komisija (4), 2017). Crna Gora je nedugo nakon proglašenja neovisnosti ${ }^{6}$ potpisala Sporazum o stabilizaciji i pridruživanju, a koji je na snagu stupio 2010. godine. Status službenoga kandidata je Crnoj Gori odobren 2010. godine, a pregovori o članstvu su započeti 2012. godine (Europska komisija (5), 2017).

Nadalje, jedna od zemalja Zapadnoga Balkana sa svakako najvećim izazovima i specifičnostima u integracijskome procesu je Bosna i Hercegovina, a koja je Sporazum o stabilizaciji i pridruživanju potpisala 2008. godine, te je on stupio na snagu 2015. godine. Unatoč službenome zahtjevu za članstvo, koji je predan 2016. godine, Bosna i Hercegovina još uvijek ima status potencijalne kandidatkinje, te čeka službenu odluku Europske komisije i Vijeća ministara. Uspješnost i dinamika Bosne i Hercegovine u procesu uključivanja u EU će uvelike biti determinirana suočavanjem sa unutarnjim problemima, provedbom efikasnih

Crna Gora je neovisnost proglasila 2006. godine. 
strukturnih reformi te daljnjim poticanjem i normalizacijom političkih odnosa (Europska komisija (6), 2017).

Kosovo je potpisalo Sporazum o stabilizaciji i pridruživanju 2015. godine i on je stupio na snagu 2016. godine. Ipak, specifičnost Kosova u odnosu na ostale zemlje Zapadnoga Balkana se ogleda u nepriznavanju neovisnosti ${ }^{7}$ o određenoga broja članica EU te status protektorata Unije, karakteriziran implementacijom policijske i civilne misije (EULEX). Kosovo je ostvarilo određeni napredak u jačanju institucija, smanjivanju korupcije te sprječavanju međuetničkih i međureligijskih sukoba. Međutim, ključni izazovi ostaju daljnje reforme u svim aspektima politike, građanstva i gospodarstva (Europska komisija (7), 2017).

Daljnji korak prema integraciji zemalja Zapadnoga Balkana predstavlja i strategija Europske Komisije iz 2018. godine za Vjerodostojnu perspektivu proširenja $i$ pojačanu suradnju EU sa Zapadnim Balkanom (Europska komisija (9), 2018). U njoj se navode prioriteti i područja u kojima je potrebna veća zajednička suradnja te posebni izazovi s kojima se Zapadni Balkan suočava, s posebnim naglaskom na temeljite reforme i razvoj dobrosusjedskih odnosa. Također, Strategija se orijentira na šest ključnih inicijativa tj. jačanje vladavine prava, pojačana suradnja u području sigurnosti i migracija uz pomoć zajedničkih istražiteljskih timova i europske granične i obalne straže, širenje energetske unije EU-a na zapadni Balkan te smanjenje troškova rominga i uvođenje širokopojasnog interneta u regiji. U Strategiji se naglašava kako EU treba biti spremna prihvatiti nove zemlje članice kada one ispune kriterije. Novi pristup zemljama Zapadnoga Balkana upućuje kako bi Crna Gora i Srbija mogle postati punopravne članice EU najranije 2025. godine, pri čemu se kao ključna ističe 2019. godina. Naime, tada bi obje zemlje trebale ispuniti prijelazna mjerila vezana za poglavlja pravosuđa i unutarnjih poslova. Nadalje, u slučaju Srbije je kao ključna obveza/zahtjev označeno normaliziranje odnosa sa Kosovom. Naravno, predviđene datume ne treba shvatiti kao propisani rako za sljedeće proširenje, već kao perspektivu koja može biti ostvarena isključivo kvalitetnim ispunjavanjem postavljenih zahtjeva. O kvalitetnoj pripremi će uvelike ovisiti i dugoročni učinci punopravnoga članstva u EU za ovu skupinu zemalja.

\section{POTENCIJALNI UČINCI UKLJUČIVANJA U EU NA GOSPODARSTVA ZEMALJA ZAPADNOG BALKANA}

Općenito, ključne motive uključivanja ove skupine zemalja u europske integracijske procese je moguće podijeliti na ekonomske i političke. Prema Whalleyu

Kosovo je neovisnost proglasilo 2008. godine. Ipak, neovisnost države još uvijek Grčka, Cipar, Rumunjska, Slovačka i Španjolska smatraju nelegitimnom. 
(1996), najvažniji motiv sudjelovanja zemalja u integracijskim procesima je temeljen na ideji "kako će se recipročnom trgovinskom liberalizacijom omogućiti bolji i lakši pristup tržištima od kojih će sve uključene strane imati koristi”. Velde i Fanbulleh (2003) ističu kako zemlje uključene u proces integracije ostvaruju pozitivne učinke koji se reflektiraju kroz pojačani gospodarski rast i razvoj, povećanje trgovine te sve veći priljev inozemnih izravnih investicija. Na sličnome tragu je i Mathews (2003), koji kao najvažnije motive uključivanja zemalja u integracijske procese ističe upravo povećanje međunarodne trgovine, učinke strane konkurencije te koristi iz poboljšane alokacije resursa. Također, uključivanjem u pojedine integracije zemljama se otvara i pojednostavljuje pristup tržištima ostalih zemalja članica, stvaraju se uvjeti za veći priljev inozemnih izravnih investicija, privlačenje međunarodne pomoći. Nadalje, na prethodno navedene autore se nadovezuju Kandžija i Cvečić (2010), koji kao najvažnije motive integriranja ističu povećanje konkurentnosti nacionalnih gospodarstava, povećanje tržišta, ostvarenje ekonomije obujma, izazove povećane inozemne konkurencije, poticanje investicija te učinkovitiju proizvodnju. Grgić i Bilas (2012) ističu kako je svim teorijskim motivima integriranja zajednička karakteristika "smanjivanje barijera u trgovini te diskriminacija trgovine s ostalim ne-članicama”. Wu (2004), provedenim istraživanjem u zemljama u razvoju, ističe institucionalna ograničenja kao ključnu prepreku sudjelovanja ovih zemalja u integracijskim procesima, budući da ona usporavaju njihovu dublju integraciju. Navedeno je u svakom slučaju u velikoj mjeri primjenjivo i na zemlje Zapadnoga Balkana.

Uključivanjem u EU zemlje Zapadnoga Balkana će postati dio Unutarnjega tržišta EU, čime će se poduzećima i ostalim gospodarskim subjektima „otvoriti“ mogućnost poslovanja na velikom prostoru, sa preko 507 milijuna potencijalnih potrošača. Isto tako, uključivanjem u Unutarnje tržište stanovništvo i poslovni subjekti će dobiti mogućnost iskorištavanja i „konzumiranja“ tzv. četiri slobode tj. sloboda kretanja, roba, usluga, kapitala i ljudi. Otvorenost tržišta te mogućnost „trgovine bez granica“ otvoriti će mogućnosti preuzimanja novih tehnologija te mogućnost tržišne utakmice sa ostalim europskim i globalnim subjektima. Naravno, u novim, dinamičnim tržišnim uvjetima, pretpostavka uspjeha će biti stalan napredak i inovativnost tj. prilagodba suvremenim tržišnim uvjetima. Upravo novi uvjeti te povećana strana konkurencija će predstavljati najveću prijetnju, ali i izazov „domaćim“ poduzećima, koja će se naći u situaciji, u kojoj im opstanak ovisi o postizanju izvrsnosti. S druge strane, mladim ljudima, a posebno onima obrazovanim, pružiti će se dodatne mogućnosti studiranja i usavršavanja na inozemnim obrazovnim i znanstvenim institucijama. Stjecanjem međunarodnih znanja, novim iskustvima te njihovom implementacijom, ostvariti će se pretpostavke za daljnji gospodarski rast ovih zemalja, pri čemu ključni izazov predstavlja ostvarivanje međunarodne konkurentnosti, a koju je moguće definirati kao „sposobnost zemlje da u slobodnim i ravnopravnim tržišnim uvjetima proizvede 
robe i usluge koje prethodno prolaze test međunarodnog tržišta osiguravajući zadržavanje i dugoročno povećanje realnog dohotka stanovništva " (OECD, 2015) ili „,kao sposobnost zemlje da ostvaruje kontinuirani gospodarski rast, što u konačnici doprinosi povećanju blagostanja stanovništva, uz pretpostavku povećanja zaposlenosti i smanjivanje i/ili održavanje stabilnih razina javnog duga. Nadalje, uz nužnost povećanja izvoza, zemlje se mora prilagoditi i globalizacijskim trendovima, a što stavlja značajan naglasak na ulaganja u istraživanje i razvoj, povećanje izvoza proizvoda visokih tehnologija te stvaranje povoljnog okruženja za priljev stranih direktnih investicija“" (Šegota et al., 2017).

Povezano sa prethodno navedenim, ekonomska teorija kao najvažnije prednosti punopravnog članstva u EU ističe (Kandžija, Cvečić, 2010): 1) povećane mogućnosti gospodarskog djelovanja i suradnje, 2) mobilnost rada i studiranja kroz iskorištavanje prednosti Unutarnjeg tržišta i Europske ekonomske i monetarne unije, 3) zaštitu okoliša, suradnju u pravosuđu, borbu protiv kriminala, zaštitu potrošača, 4) veću kulturnu raznolikost te bolje razumijevanje među pripadnicima različitih naroda te 5) jačanje pregovaračke moći i utjecaja EU u svijetu.

Političke motive integriranja je moguće identificirati u smislu ostvarenja ciljeva nacionalne sigurnosti (Grgić i Bilas, 2012) te jačanje pregovaračke moći, a koja predstavlja temelj pokretanja strukturnih i političkih reformi u pojedinoj zemlji (Whalley, 1996). Ostvarivanjem punopravnoga članstva u EU, zemlje Zapadnoga Balkana će biti uključene u proces donošenja odluka i definiranja zakona, mjera, instrumenata, strateških pravaca te ostalih relevantnih akata, potrebnih za funkcioniranje cjelokupnoga sustava EU. Također, ove skupine zemalja će se naći u grupi stabilnih europskih država, što će pomoći daljnjoj demokratizaciji društva te jačanju institucija. Jedan od najvažnijih segmenata članstva u EU za ovu skupinu zemalja predstavlja i sigurnost. Naime, ova skupina zemalja je veliki dio svoje povijesti bila obilježena političkim i vojnim previranjima, a koja su uvelike usporila njihov gospodarski napredak. Funkcioniranje u stabilnome okruženju, ovim će zemljama svakako omogućiti iskorištavanje potencijala za postizanje ujednačenoga gospodarskoga rasta.

Također, ključne učinke integriranja je moguće definirati i na temelju istraživanja Aplleyarda (1992) te Grgića i Bilas (2012). Pritom, Aplleyard (1992) dijeli ključne učinke integriranja na statičke i dinamičke. Skupinu statičkih učinaka čine akumulacijski, alokacijski te lokacijski učinci. Akumulacijski učinci obuhvaćaju stvaranje i skretanje trgovine, učinke na uvjete razmjene te učinke na konkurentnost. Nadalje, alokacijski učinci su vezani na učinke u srednjem i dugom roku, dok lokacijski učinci predstavljaju prostornu alokaciju resursa. Dinamički učinci se manifestiraju u dugome roku kroz ostvarenje optimuma proizvodnje, ekonomije obujma te učinke na investicije i bilancu plaćanja. Na temelju prethodne 
podjele, Grgić i Bilas (2012) razlikuju pozitivne i negativne učinke integriranja. Autori ističu kako se pozitivni učinci ogledaju kroz ostvarenje ekonomije obujma, povećani priljev izravnih stranih investicija, suočavanje sa rastućom konkurencijom te jačanje pregovaračkih pozicija i moći. S druge strane, kao ključne negativne učinke je moguće istaknuti i situacije potencijalnih ograničavanja pregovaračkih kapaciteta, smanjenje entuzijazma za multilateralne pregovore, skretanje trgovine, isključenost najslabije razvijenih zemalja te ograničenja koja proizlaze iz složenih i neusklađenih pravila podrijetla.

Važan čimbenik ostvarenja punopravnoga članstva u EU zemalja kandidata i potencijalnih kandidata predstavlja mogućnost korištenja Instrumenta pretpristupne pomoći (IPA). Naime, IPA je osnovana 2007. godine, kada je zamijenila dotadašnje programe namijenjene zemljama kandidatima i potencijalnim kandidatima tj. ISPA, PHARE, CARDS I SAPARD (Ministarstvo financija Republike Hrvatske, 2017). Smisao Programa se ogleda u pomoći zemljama u stvaranju uvjeta za usvajanje pravne stečevine i ostalih zahtjeva EU te pripremu zemlje za korištenje strukturnih fondova, prvenstveno kroz aktivnosti javnih tijela, nevladinoga i privatnoga sektora. Aktivnosti programa IPA I su trajale od 2007.-2013 ${ }^{8}$. godine, kada je zemljama bilo na raspolaganju 11,5 milijardi eura. U razdoblju 2014.2020. godine, aktivnosti se financiraju u okviru IPA-e II, čiji proračun iznosi 11,7 milijardi eura (Europska komisija (8), 2017). Kao ključna područja IPA-e II su određeni reforma javne uprave, vladavina prava, održivo gospodarenje, ljudi te poljoprivreda i ruralni razvoj. Alokacija sredstava ${ }^{9}$ IPA II programa u zemljama Zapadnoga Balkana je prikazana u Tablici 5.

Tablica 5. Alokacija IPA II programa u zemljama Zapadnoga Balkana u razdoblju 2014.2020. godine (u milijunima eura)

\begin{tabular}{|c|c|c|c|c|c|c|}
\hline Zemlja/Godina & 2014. & 2015. & 2016. & 2017. & $\begin{array}{c}2018 .- \\
2020 .\end{array}$ & Ukupno \\
\hline Albanija & 83,7 & 86,9 & 89,7 & 92,9 & 296,3 & 649,5 \\
\hline $\begin{array}{c}\text { Bosna i Herce- } \\
\text { govina }\end{array}$ & 39,7 & 39,7 & 42,7 & 43,7 & $*$ & 165,8 \\
\hline Makedonija & 85,7 & 88,9 & 91,6 & 94,9 & 303,1 & 664,2 \\
\hline Kosovo & 83,8 & 85,9 & 88,7 & 91,9 & 295,2 & 645,5 \\
\hline Crna Gora & 39,6 & 35,6 & 37,4 & 39,5 & 118,4 & 270,5 \\
\hline Srbija & 195,1 & 201,4 & 207,9 & 215,4 & 688,2 & $1,508,0$ \\
\hline
\end{tabular}

Iznosi će biti određeni u kasnijoj fazi

Izvor: izrada autora na temelju Europska komisija (8), 2017.

$8 \quad$ Realizacija započetih projekata još uvijek traje.

9 Potrebno je razlikovati pojmove alokacije i iskorištenosti dostupnih EU financijskih sredstava. 
Podatci iz Tablice 3. upućuju kako zemlje Zapadnoga Balkana imaju na raspolaganju značajna sredstava iz pretpristupnoga programa, pri čemu su najveća namijenjena Srbiji. Ipak, uspješnost te ostvarivanje pozitivnih gospodarskih učinaka kroz korištenje namijenjenih sredstava u zemljama Zapadnoga Balkana će prvenstveno ovisiti o njihovim apsorpcijskim kapacitetima. Prema Boeckhoutu i suradnicima (2002), apsorpcijski kapacitet označava razinu do koje je zemlja sposobna učinkovito iskoristiti financijska sredstava iz EU financijskih instrumenata, u svrhu ostvarenja gospodarskoga rasta i ostvarenja socijalne kohezije. Host i Ivandić (2014) navode kako problem apsorpcije u zemlji postoji u slučaju kada ,država koja prima financijsku potporu ne uspijeva postići potpunu alokaciju EU sredstava ili 100\% unaprijed određene ciljane vrijednosti, a što se najčešć javlja zbog ograničene administrativne sposobnosti zemlje pri donošenju i implementaciji zadanih operativnih programa". Također, autori ističu kako „,gornja granica apsorpcijskih kapaciteta zemlje korisnice iznosi 4\% BDP-a“. Kandžija i Cvečić (2010), kao najvažnije izazove pri iskorištavanju raspoloživih EU sredstava, ističu nužnost pravovremenoga određivanja odgovornosti, razvoj računovodstvenih i revizijskih praksi, oblikovanje sustava i procedura, te mogućnost savladavanja financijskih nepravilnosti i procedura. Uvažavajući suvremene konvergencijske pretpostavke, kao ključni čimbenik uspješne apsorpcije je moguće istaknuti ljudski kapital, tj. važnost obrazovane i stručne radne snage, a što stavlja veliki izazov pred nositelje gospodarskih i političkih aktivnosti.

Mjerenje učinaka korištenja strukturnih instrumenata na ostvarenje gospodarskoga rasta u zemljama je započeto u 1980-im godinama, kada je razvijen HERMIN model, koji predstavlja najčešće korišten način predviđanja i kvantificiranja učinaka korištenja raspoloživih financijskih sredstava (Devčić i Šostar, 2011). Korištenjem ovoga modela Bradley i Zaleski (2002), uz razmatranje scenarija „,sa“ i „bez“ korištenja strukturnih sredstava, zaključuju kako implementacija strukturnih sredstava utječe na povećanje BDP-a od 1\%. Također, istraživanja Europske komisije upućuju kako će sredstva kohezijske politike EU u razdoblju 201.-2020. godine rezultirati povećanjem razine BDP-a za $\%$ te rastom zaposlenosti od 1\%. Navedeno zasigurno predstavlja izazov i za zemlje Zapadnoga Balkana.

Zemlje Zapadnoga Balkana se u suvremenim gospodarskim i globalizacijskim uvjetima suočavaju i sa potrebom modernizacije i osuvremenjivanja te izazova ostvarenja pametnoga, održivoga i uključivoga rasta, a što je kao prioritet postavljeno strategijom EUROPA 2020. Ipak, vrijeme implementacije Strategije se polako približava kraju te su upitni njezini konkretni učinci. Eventualne neuspjehe Strategije je moguće opravdati i razornim učincima globalne ekonomske krize te opširnim ciljevima, uz nedostatak međusobne koordinacije i suradnje. Međutim, budućnost EU počiva na ostvarenju društva znanja i digitalizaciji te je potrebno i nakon 2020. godine, novim strateškim pravcima i mjerama, nastaviti u započetom 
smjeru. Navedenom razvojnom pravcu se moraju prilagoditi i zemlje Zapadnoga Balkana, a što je prepoznato 2013. godine, definiranjem Regionalne strategije za inovacije zemalja Zapadnoga Balkana (Svjetska banka (11), 2017). Strategija je usmjerena na unaprjeđenje ljudskih potencijala, iskorištavanje raspoloživih EU financijskih sredstava te stvaranje političke podloge za stalno promicanje reformi politika i jačanje kapaciteta radi mobiliziranja vanjskih sredstava za financiranje istraživanja. Regionalna suradnja zemalja regije u području istraživanja i razvoja također će rezultirati pozitivnim pritiskom okoline te će predstavljati pokazatelj orijentacije zemalja za prilagodbu Europskomu istraživačkom prostoru (ERA) U kontekstu Strategije, kao ključni kvantitativni cilj je određeno povećanje ulaganja u istraživanje i razvoj na 1,5\% BDP-a do 2020. godine. Ostvarenje ovoga cilja je, imajući u vidu trenutačnu situaciju, ipak teško očekivati do 2020. godine.

\section{ZAKLJUČAK}

Provedenim istraživanjem je utvrđena nepovoljna gospodarska i socijalna situacija u zemljama Zapadnoga Balkana, a koja je kao najvažniji gospodarski i strateški cilj ove skupine zemalja odredila punopravno članstvo u EU. Na putu prema ostvarenju propisanoga cilja ove zemlje moraju zadovoljiti složene kriterije i procedure propisane od strane EU te provesti efikasne i sveobuhvatne strukturne reforme. U radu su identificirani ključni potencijalni učinci uključivanja ove skupine zemalja u EU, s posebnim naglaskom na mogućnosti poslovanja na velikom europskom tržištu, što će uvelike utjecati na poboljšanje njihovih gospodarskih performansi te međunarodne konkurentnosti. Također, kao nastavak dosadašnjih istraživanja, istaknuta je krucijalna važnost korištenja dostupnih EU financijskih sredstava te unaprjeđenje apsorpcijskog kapaciteta, u funkciji ubrzavanja gospodarskoga rasta ti smanjivanja nezaposlenosti, a koja je prepoznata kao najveći problem ove skupine zemalja. Nadalje, punopravnim članstvom u EU, ove će zemlje imati mogućnosti ostvarenja napretka u području obrazovanja i usavršavanja, čime će najviše profitirati mlado i obrazovano stanovništvo, a koje u suvremenim uvjetima predstavlja ključni čimbenik konvergencije. Buduća istraživanje ove tematike bi se trebala usmjeriti dubinska istraživanja svake od navedenih zemalja, s potrebom konkretnoga kvantificiranja i projiciranja učinaka punopravnoga članstva u EU.

\section{LITERATURA}

1. Altić Slukan, M. (2009), Hrvatska kao zapadni Balkan - geografska stvarnost ili nametnuti identitet?, Društvena istraživanja. 2 (112), str. 401-403. 
2. Appleyard, R., T. (1992), Migration and Development: A Global Agenda for the Future. International Migration, 30 (1), 17-31.

3. Boeckhout, S., Boot, L., Hollanders, M., Reincke, K.J., Maarten de Vet, J. (2002) Key Indicators for Candidate Countries to Effectively Manage the Structural Funds. NEI Regional and Urban Development. Principal Report for EC DG Regio/DG Enlargement. Rotterdam

4. Bradley, J., Zaleski, J. (2002) Modelling EU accession and Structural Fund impacts using the new polish HERMIN model. Working paper.

5. Članak 49 Ugovora o EU i Ugovora o funkcioniranju EU, http://www.mvep. hr/custompages/static/hrv/files/pregovori/111221-lisabonski-prociscena.pdf (pregledano 21.prosinca 2017.)

6. Devčić, A., Šostar, M. (2011), Modeli mjerenja realnih učinaka fondova EU na gospodarski razvoj, Ekonomski vjesnik - Econviews - Review of Contemporary Enterpreneurship, Business, and Economic Issues, 25(1), str. 133-144.

7. Emerson, M., Aydinn, S., De Clark-Sachess, J., Noutcheva, G. (2007) Just what is this , absorption capacity “ of the European Union?. Center for European Policy Studies. Brisel

8. Encyclopedia Britannica (1993) Encyclopedia Britannica Inc, vol. 1. str. 833-835.

9. Europska komisija (1), 2017, dostupno na: https://ec.europa.eu/neighbourhood-enlargement/policy/glossary/terms/integration-capacity_en (pregledano 18.prosinca 2017.)

10. Europska komisija (2), (2017), dostupno na: https://ec.europa.eu/neighbourhood-enlargement/countries/detailed-country-information/fyrom_en (pregledano 18.prosinca 2017.)

11. Europska komisija (3), (2017), dostupno na: https://ec.europa.eu/neighbourhood-enlargement/countries/detailed-country-information/albania_en (pregledano 18. prosinca 2017.)

12. Europska komisija (4), (2017), dostupno na: https://ec.europa.eu/neighbourhood-enlargement/countries/detailed-country-information/serbia_en (pregledano 18. prosinca 2017.)

13. Europska komisija (5), (2017), dostupno na: https:/ec.europa.eu/neighbourhood-enlargement/countries/detailed-country-information/montenegro_en (pregledano 18. prosinca 2017.)

14. Europska komisija (6), (2017), dostupno na: https://ec.europa.eu/neighbourhood-enlargement/countries/detailed-country-information/bosnia-herzegovina_en (pregledano 18.prosinca 2017.) 
15. Europska komisija (7), (2017), dostupno na: https://ec.europa.eu/neighbourhood-enlargement/countries/detailed-country-information/kosovo_en (pregledano 18. prosinca 2017.)

16. Europska komisija (8), (2017), dostupno na: https://ec.europa.eu/neighbourhood-enlargement/instruments/overview_en (pregledano 18.prosinca 2017.)

17. Europska komisija (9), (2018), dostupno na: https:/ec.europa.eu/commission/sites/beta-political/files/six-flagship-initiatives-support-transformation-western-balkans_en.pdf (pregledano 21. lipnja 2018.)

18. Eurostata (2018), dostupno na: http://ec.europa.eu/eurostat/tgm/table. $\mathrm{do} ? \mathrm{tab}=$ table\&init $=1 \&$ language $=$ en $\&$ pcode $=$ tec00114\&plugin $=1 \quad$ (pregledano 22. lipnja 2018.)

19. Grgić, M., Bilas, V. (2012) Teorija regionalnih ekonomskih integracija. Sinergija nakladništvo, d.o.o. Zagreb

20. Host, A., Ivandić, V. (2014) Absorption Capacity of the EU Financial Assistance, Kandžija, V. (ur.) Absorption Capacity of EU Pre-accession Programs in the Western Balkan Countries. CEMAFI International. Nica

21. Hupchick, D., Cox, H. (2001) The Palgrave Concise historical Atlas of the Balkans. Palgrave, New York

22. Kandžija, V., Cvečić, I. (2010) Ekonomika i politika Europske unije. Ekonomski fakultet Sveučilišta u Rijeci. Rijeka

23. Klemenčić, M. (1999) Jugoistočna Europa - definicija pojma i razvitak političkog zemljovida. Rad prezentiran u okviru Međunarodnoga znanstvenoga skupa "Jugoistočna Europa 1918.-1995". Hrvatska matica iseljenika i Hrvatski informativni centar. Zagreb.

24. Mathews, A. 2003. Regional Integration and Food security in Developing Countries. Food and Agriculture Organization of the United Nations. Rim.

25. Milardović, A. (2000) Zapadni Balkan: pojam, ideje i dokumenti o rekonstrukciji Balkana u procesu globalizacije, Pan liber: Osijek, Zagreb, Split

26. Topalović, D. (2000) Balkanska Europa, Diorama. Zagreb

27. Ministarstvo vanjskih i europskih poslova Republike Hrvatske, 2017., dostupno na: http://www.mvep.hr/hr/hrvatska-i-europska-unija/pregovori/ (pregledano 21.prosinca 2017)

28. OECD 2015. dostupno na: http:/www.oecd.org/cfe/regional-policy/regionalcompetitiveness.htm (pregledano 15. studenog 2017.)

29. Sauron, J., L. 1997. Enlargissement a l'est, 1848. - 1998. U: Du Juris, C. (ur.), Le print emps des peuple. Europska Komisija.Brisel

30. Svjetska banka (1) 2018. dostupno na: https://data.worldbank.org/indicator/ NY.GDP.PCAP.CD (pregledano 25. studenog 2017.) 
31. Svjetska banka (2) 2018. dostupno na: https://data.worldbank.org/indicator/ NY.GDP.MKTP.KD.ZG (pregledano 25. studenog 2017.)

32. Svjetska banka (3) 2018. dostupno na: https://data.worldbank.org/indicator/ NV.AGR.TOTL.ZS (pregledano 25. studenog 2017.)

33. Svjetska banka (4) 2018. dostupno na: https://data.worldbank.org/indicator/ NV.IND.TOTL.ZS (pregledano 25. studenog 2017.)

34. Svjetska banka (5) 2018. dostupno na: https://data.worldbank.org/indicator/ NV.SRV.TETC.ZS (pregledano 25. studenog 2017.)

35. Svjetska banka (6) 2018. dostupno na: https://data.worldbank.org/indicator/ SL.AGR.EMPL.ZS (pregledano 25. studenog 2017.)

36. Svjetska banka (7) (2018), dostupno na: https://data.worldbank.org/indicator/SL.IND.EMPL.ZS (pregledano 25. studenog 2017.)

37. Svjetska banka (8) 2018. dostupno na: https://data.worldbank.org/indicator/ SL.SRV.EMPL.ZS (pregledano 25. studenog 2017.)

38. Svjetska banka (9) 2018. dostupno na: https://data.worldbank.org/indicator/ BN.CAB.XOKA.GD.ZS (pregledano 25. studenog 2017.)

39. Svjetska banka (10) 2018. dostupno na: https://data.worldbank.org/indicator/ SL.UEM.TOTL.ZS (pregledano 25. studenog 2017.)

40. Svjetska banka (11) 2018. dostupno na: http://www.worldbank.org/hr/news/ press-release/2013/10/25/western-balkan-countries-develop-joint-strategy-for-innovation-based-economic-growth (pregledano 25. studenog 2017.)

41. Šegota, A., Tomljanović, M., Huđek, I. (2017), Contemporary approaches to measuring competitiveness - the case of EU member states, Zbornik Ekonomskog fakulteta u Rijeci-časopis za ekonomsku teoriju i praksu/Proceedings of Rijeka Faculty of Economics: Journal of Economics and Business, 35 (1) str. 123-150.

42. Velde, D.W., Fahnbulleh, M. (2003) Investment related provisions in regional tradea greements, Regional Integration and Poverty. Overseas Development Institute. London.

43. Whaley, J. (1996) Why do countries seek regional trade agreements? National Bureau of Economic Research. University of Chicago Press. Chicago.

44. Wu, J., P. (2004) Measuring and Explaining Levels of Regional Economic Integration. University of Bonn, Center for European Integration Studies (ZEI). Bon. 


\title{
Marko Tomljanović, PhD
}

University of Rijeka, Faculty of Economics and Business, Rijeka, Croatia marko.tomljanovic@efri.hr

\section{ACCESSION OF WESTERN BALKAN COUNTRIES TO THE EUROPEAN UNION - CURRENT STATE AND POTENTIAL ECONOMIC EFFECTS}

Received: June 26, 2018

Accepted: August 31, 2018

Review

\begin{abstract}
Faced with the unfavorable economic and social situation, which has emerged as a direct consequence of previous war events and political turbulences, Western Balkan countries have identified the realization of the full EU membership as the most important economic and strategic goal. The aim of the conducted research is to examine the current position of this group of countries in the European integration processes by examining the theoretical and historical insights on integration trends in Western Balkan countries and analyzing the economic situation. The purpose of the research is to determine the potential effects of the full EU membership on achievement of economic and social progress in Western Balkan countries. The conducted research found a significant lag behind of this group of countries toward the EU average, which is a challenge in the implementation of effective structural reforms. With the full EU membership, this group of countries will be able to operate on the EU Internal Market and be available to use the EU financial instruments, which will present the basis for significant acceleration and improvement of economic performance and an increase in international competitiveness.
\end{abstract}

Keywords: EU, IPA, Copenhagen criteria, enlargement policy, Western Balkan JEL: $F 15, F 63$ 